\title{
Effect of temperature on the orthodontic clinical applications of niti closed-coil springs
}

\author{
Eduardo Espinar-Escalona ${ }^{1}$, José-María Llamas-Carreras ${ }^{1}$, José-María Barrera-Mora ${ }^{1}$, Camilo Abalos- \\ Lasbrucci ${ }^{1}$, Francisco-Javier Gil-Mur ${ }^{2}$
}

${ }^{1}$ Grupo de Ortodoncia. Facultad de Odontología. Universidad de Sevilla

${ }^{2}$ Dept. C.Materiales e Ingeniería Metalúrgica. ETSEIB. Universidad Politécnica de Cataluña. Barcelona. Spain

Correspondence:

Dept. C. Materials i Eng. Metalúrgica

Universidad Politécnica de Cataluña

Av. Diagonal 647.

08028-Barcelona. Spain

francesc.xavier.gil@upc.edu

\author{
Espinar-Escalona E, Llamas-Carreras JM, Barrera-Mora JM, Abalos- \\ Lasbrucci C, Gil-Mur FJ. Effect of temperature on the orthodontic clini- \\ cal applications of niti closed-coil springs. Med Oral Patol Oral Cir Bucal. \\ 2013 Jul 1;18 (4):e721-4.
}

http://www.medicinaoral.com/medoralfree01/v18i4/medoralv18i4p721.pdf

Received: 19/01/2013

Accepted: $15 / 02 / 2013$

\begin{abstract}
NiTi spring coils were used to obtain large deformation under a constant force. The device consists on a NiTi coil spring, superelastic at body temperature, in order to have a stress plateau during the austenitic retransformation during the unloading. The temperature variations induced changes in the spring force.

Objectives: The aim of this study is to investigate the effect of the temperature variations in the spring forces and corrosion behaviour simulating the ingestion hot/cold drinks and food.

Study Design: The springs were subjected to a tensile force using universal testing machine MTS-Adamel (100 N load cell). All tests were performed in artificial saliva maintained at different temperatures. The corrosion tests were performed according to the ISO-standard 10993-15:2000.

Results: The increase in temperature of $18^{\circ} \mathrm{C}$ induced an increase in the spring force of $30 \%$. However, when the temperature returns to $37^{\circ} \mathrm{C}$ the distraction force recovers near the initial level. After cooling down the spring to $15^{\circ} \mathrm{C}$, the force decreased by $46 \%$. This investigation show as the temperature increase, the corrosion potential shifts towards negative values and the corrosion density is rising.

Conclusions: The changes of the temperatures do not modify the superelastic behaviour of the NiTi closed-coil springs. The corrosion potential of NiTi in artificial saliva is decreasing by the rise of the temperatures.
\end{abstract}

Key words: Superelasticity, NiTi, springs, orthodontic, coils, recovery, temperature. 


\section{Introduction}

NiTi shape memory alloys coil springs have been a useful intraoral tool for space closure and opening in different orthodontic therapies. Open-coil springs are designed to deliver an expansion force as indicated in space opening (different movement ofteeth), whereas the closed-coil springs are intended to deliver, compressive forces (ex. retraction of the canines). These NiTi springs produce continuous, light forces over range of activation. Conventional coil springs (stainless steel, titanium) display a linear plot in the force deflection graph; whereas superelastic NiTi springs show a typical force plateau. The stress-strain curve for a superelastic material shows that the stress which induced the phase transformation (martensite-parent) upon unloading takes place at a fairly constant stress over a significant range of wire activation. These low and continuous loads are adequate to biological response (1-3).

It is generally assumed that the optimal tooth movement is achieved by applying forces that are low in magnitude and continuous in nature. Such forces minimize tissue destruction and produce a relatively constant stress in the periodontal ligament during tooth movement (4). The superelasticity of NiTi archwires allows the orthodontist to apply an almost continuous light force with larger activations that results in the reduction of tissue trauma and the patient discomfort, thus facilitating enhanced tooth movement (5).

Oral cavity is one of the most inhospitable environments in the human body. Therefore, orthodontic archwires, coils or brackets are subject to larger temperature variations than most other parts, coping with ice cold temperatures $\left(5^{\circ} \mathrm{C}\right)$ through to hot coffee and soup $\left(70^{\circ} \mathrm{C}\right)$. Many works about effect of different parameters on the corrosion behaviour of NiTi orthodontic wires have been published $(6,7)$ but few have rarely investigated the effect of temperature on the corrosion behaviour of NiTi alloys by electrochemical techniques in artificial saliva.

NiTi alloys combine their shape memory effect and superelasticity with excellent mechanical properties and a good biocompatibilty $(3,8)$. Despite of these advantages, it is necessary to study the effect of the variations of temperature which can produce important changes in the load applied to the teeth and the corrosion behaviour. These temperature variations in the spring forces simulate the ingestion hot/cold drinks and food.

\section{Material and Methods}

The device is simple and consists of a NiTi spring that is commercially available for orthodontic applications. GAC-Orthospain consists of 52\% at nickel and $48 \%$ at titanium.

Fifty NiTi closed 300 g coil springs were obtained by GAC-Orthospain (reference 10-000-20). The springs have an external diameter of $1.1 \mathrm{~mm}$, a wire diameter of $0.3 \mathrm{~mm}$, a working length of $2.7 \mathrm{~mm}$ (9 coils), and a theoretical discharge force of $300 \mathrm{gf}$ (grames/force) (this is the force in which the unloading plateau should occur).

The springs were subjected to a tensile force using universal testing machine MTS-Adamel (100 N load cell). All tests were performed in artificial saliva maintained at different temperatures. The chemical composition of the artificial saliva is shown in table 1. The following tensile test were performed: A tensile force was applied at a strain rate of $2 \mathrm{~mm} / \mathrm{min}$ up to $8 \mathrm{~mm}$ (3.9 times the original length) followed by a complete unloading at 1 $\mathrm{mm} / \mathrm{min}$.

Table 1. Chemical composition of the artificial saliva.

\begin{tabular}{|c|c|}
\hline Chemical product & Composition $\left(\mathbf{g} / \mathbf{d m}^{\mathbf{3}}\right)$ \\
\hline $\mathrm{K}_{2} \mathrm{HPO}_{4}$ & 0.20 \\
\hline $\mathrm{KCI}$ & 1.20 \\
\hline $\mathrm{KSCN}$ & 0.33 \\
\hline $\mathrm{Na}_{2} \mathrm{HPO}_{4}$ & 0.26 \\
\hline $\mathrm{NaCl}$ & 0.70 \\
\hline $\mathrm{NaHCO}$ & 1.50 \\
\hline Urea & 1.50 \\
\hline Lactic acid & up to $\mathrm{pH}=6.7$ \\
\hline
\end{tabular}

To simulate the change of temperature when ingesting food or drinks, the bath temperature was changed during the unloading period. Springs were first loaded at 2 $\mathrm{mm} / \mathrm{min}$ and unloaded at $1 \mathrm{~mm} / \mathrm{min}$. However, during unloading the displacement was stopped and fixed at 4 $\mathrm{mm}$. At this position, the temperature of the bath was changed to either $55^{\circ} \mathrm{C}$ or $15^{\circ} \mathrm{C}$ to simulate respectively the ingestion of a hot or cold beverage (9). Subsequently, the temperature was returned to $37^{\circ} \mathrm{C}$, and the unloading of the spring continued (Fig. 1).

Closed-coil springs were sectioned in order to produce corrosion testing samples. A $25 \mathrm{~mm}$ of each coil spring was cut with a sterile orthodontic plier and was isolated with wax at the point of interphase between the testing solution and the air. The corrosion tests were performed according to the ISO-standard 10993-15:2000 "Biological evaluation of medical devices. Part 15: Identification and quantification of degradation products from metals and alloys"; this standard is commonly used in orthodontic archwires corrosion (6-11). 


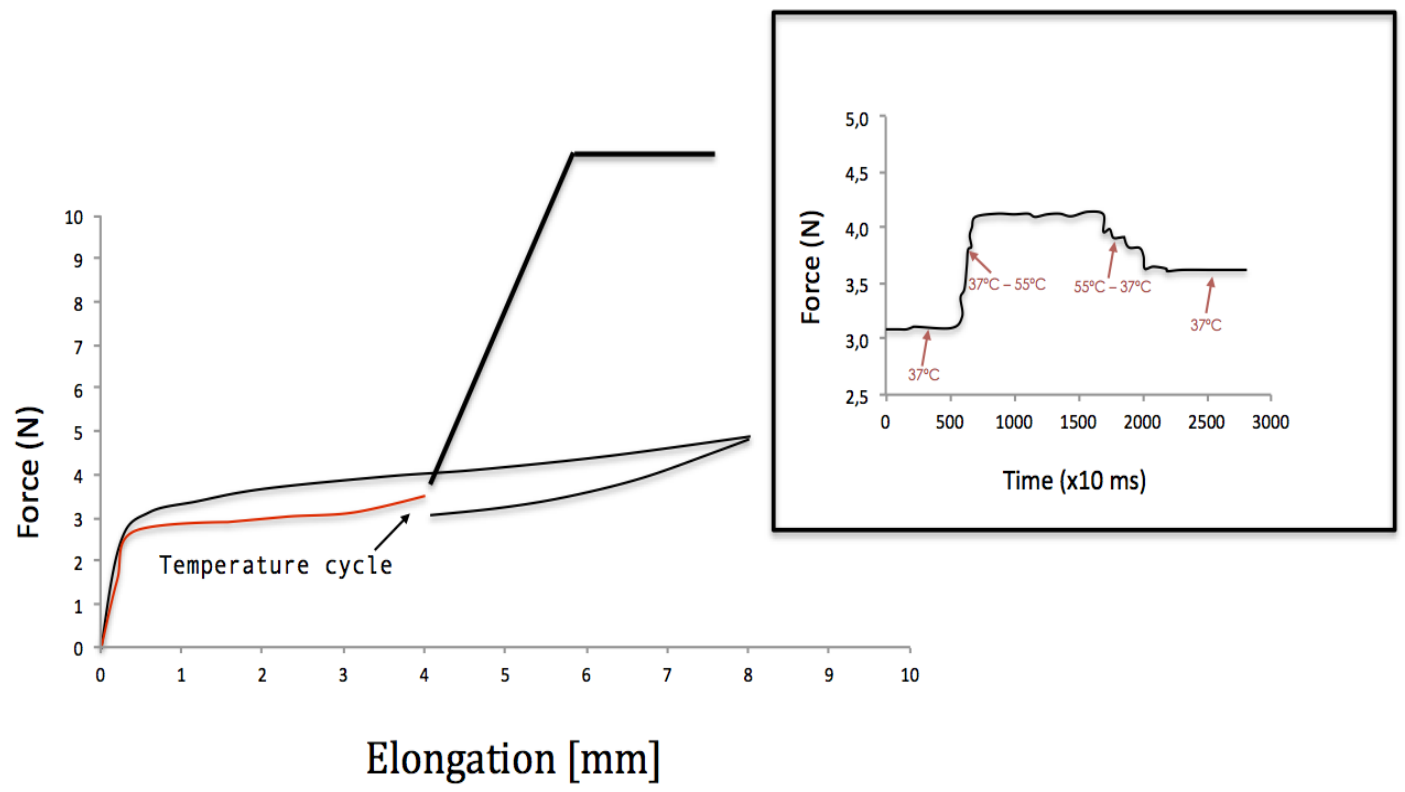

Fig. 1. Mechanical test simulating a hot ingestion of food/beverage.

The tests were carried out with a Voltalab PGZ 301 potentiostat (Radiometer, Copenhagen, Denmark) controlled by Voltamaster 4 software (Radiometer Analytical, Villeurbanne Cedex, France). The testing solution was artificial saliva that was kept at adifferent temperatures. The reference electrode was an $\mathrm{Ag} / \mathrm{AgCl} / \mathrm{KCl}$ electrode $\left(\mathrm{E}^{\mathrm{o}}=0.222 \mathrm{~V}\right)$. The auxiliary electrode used was a Platinum electrode and had a surface of $240 \mathrm{~mm}^{2}$ (Radiometer Analytical, Villeurbanne, France).

The Open Circuit Potential was monitored for 3 hours in order to allow a leveling off of the value before the polarization resistance test. The $\mathrm{CV}$ assay was performed by scanning the potential of the alloy of the sample at $0.25 \mathrm{mV} / \mathrm{s}$ with the minimum current set at $-1 \mathrm{~A}$ and the maximum at $+1 \mathrm{~A}$ with a minimum range set at $100 \mu \mathrm{A}$ between $-300 \mathrm{mV}$ and $+2000 \mathrm{mV}$ (the upper limit for TMA archwires was $+2700 \mathrm{mV}$ ) around the OCP value. Corrosion potentials (Ecorr) and corrosion currents (icorr) were recorded for the different samples tested.

\section{Results}

The increase in temperature (Fig. 1) of $180 \mathrm{C}$ induced an increase in the spring force of $30 \%$. However, when the temperature returns to $37^{\circ} \mathrm{C}$ the distraction force recovers near the initial level. After cooling down the spring to $15^{\circ} \mathrm{C}$, the force decreased by $46 \%$. As observed for an increase of temperature, the spring force returns to the original value when the temperature goes back to $37^{\circ} \mathrm{C}$. In both cases it is important to note that, although the force does not return exactly to the original level when the temperature is again $37^{\circ} \mathrm{C}$, it does when the distraction process continues. This test was repeated 10 times and the results were the same. The number of cycles did not modify the force-displacement curve.

The corrosion current densities were obtained from the polarization curves by Tafel using cathodic and anodic slopes of the polarization curves. The electrochemical parameters are shown in table 2 . These results show as the temperature increase, the corrosion potential shifts towards negative values and the corrosion density is rising.

Table 2. Corrosion parameters of NiTi coil spring at different temperatures.

\begin{tabular}{|c|c|c|}
\hline Temperature $\left({ }^{\circ} \mathbf{C}\right)$ & $\mathbf{E}_{\text {corr }}(\mathbf{V})$ & $\mathbf{I}_{\text {corr }}\left(\mathbf{A} / \mathbf{c m}^{2)}\right.$ \\
\hline 10 & $-0.090 \pm 0.011$ & $2.30110^{-8} \pm 0.0710^{-8}$ \\
\hline 20 & $-0.109 \pm 0.012$ & $2.43110^{-8} \pm 0.0510^{-8}$ \\
\hline 30 & $-0.111 \pm 0.008$ & $2.55210^{-8} \pm 0.0310^{-8}$ \\
\hline 37 & $-0.120 \pm 0.008$ & $2.63310^{-8} \pm 0.0510^{-8}$ \\
\hline 50 & $-0.140 \pm 0.012$ & $2.80010^{-8} \pm 0.0710^{-8}$ \\
\hline 60 & $-0.160 \pm 0.011$ & $2.91210^{-8} \pm 0.0910^{-8}$ \\
\hline 70 & $-0.201 \pm 0.010$ & $3.01010^{-8} \pm 0.0810^{-8}$ \\
\hline
\end{tabular}




\section{Discussion}

An important parameter that was investigated in this study is the variation of temperature during distraction. When the temperature varies, the force applied by the device changes. When heating, the martensite transforms back to austenite. However, in contrary to what has been reported by Suarez (2) for flexion forces on orthodontic wires, the force returns near the original level when the temperature returns to $37^{\circ} \mathrm{C}$. This indicates a re-transformation austenite - force induced martensite. The cooling case is simpler; there is a higher percentage of martensite and these results in a force decrease. However, this phenomenon is reversible when heating again. It is not clear though whether this increment on tissue stresses due to an increase of temperature can damage the tissues. In such a case the patient nutrition should be controlled to avoid warm food or beverage. If the stress increase does not damage the tissues, the teeth movement will continue as normal since the spring force returns to its original plateau.

The corrosion current density is directly proportional to corrosion rate, the higher values of current density is an indication of lower resistance against corrosion (9-13). The low corrosion current densities (about 108) produce an improvement of corrosion resistance, even at higher temperatures than oral environment $\left(37^{\circ} \mathrm{C}\right)(14-17)$. This fact is due to the formation of a protective oxide film constituted by titanium oxide $(3,17-21)$.

The changes of the temperatures do not modify the superelastic behaviour of the NiTi closed-coil springs. The corrosion potential of NiTi in artificial saliva is decreasing by the rise of the temperatures.

\section{References}

1. Idelsohn S, Pe-a J, Lacroix D, Planell JA, Gil FJ, Arcas A. Continuous mandibular distraction osteogenesis using superelastic shape memory alloy (SMA). J Mater Sci Mater Med. 2004;15:541-6.

2. Suárez C, Vilar T, Gil J, Sevilla P. In vitro evaluation of surface topographic changes and nickel release of lingual orthodontic archwires. J Mater Sci Mater Med. 2010; 21:675-83.

3. Espinar E, Llamas J.M, Michiardi A, Ginebra M.P, Gil F.J. Reduction of $\mathrm{Ni}$ release and improvement of the friction behavior of $\mathrm{NiTi}$ orthodontic archwires by oxidation treatments. J Mater Sci Mater Med. 2011;22 :1119-25.

4. Brantley WA, Iijima M, Grentzer TH. Temperature modulated DSC provides new insight about nickel-titanium wire transformations. Am J Orthod Dentofac Orthop. 2003;124:387-94.

5 Sfondrini MF, Cacciafesta V, Maffia E, Scribante A, Alberti G, Biesuz R, et al. Nickel release from new conventional stainless steel, recycled, and nickel-free orthodontic brackets: An in vitro study. Am J Orthod Dentofacial Orthop. 2010;137:809-15.

6. Hunt NP, Cunningham SJ, Golden CG, Sheriff M. An investigation into the effects of polishing on surface hardness and corrosion of orthodontic archwires. Angle Orthod. 1999;69:433-40.

7. Edie JW, Andreasen GF, Zaytoun MP. Surface corrosion of nitinol and stainless steel under clinical conditions. Angle Orthod. 1981;51:319-24.

8. Michiardi A, Aparicio C, Planell JA, Gil FJ. New oxidation treatment of NiTi shape memory alloys to obtain Ni-free surfaces and to improve biocompatibility. J Biomed Mater Res B Appl Biomater. 2006;77:249-56.
9. Barrabés M, Michiardi A, Aparicio C, Sevilla P, Planell J.A, Gil F.J. Oxidized nickel-titanium foams for bone reconstructions: chemical and mechanical characterization" J Mater Sci Mater Med. 2007;18:2123-9.

10. Speck KM, Fraker AC. Anodic polarization behavior of Ti-Ni and Ti-6A1-4V in simulated physiological solutions. J Dent Res. 1980;59:1590-5.

11. Andreasen G.F., Morrow R.E. Laboratory and clinical analysis of Nitinol wire. Am. J. Orthod. 1978;73:142-5.

12. Fischer-Brandies H, Es-Souni M, Kock N, Raetzke K, Bock O. Transformation behavior, chemical composition, surface topography and bending properties of five selected 0.016 "x0.022" NiTi archwires. J Orofac Orthop. 2003;64:88-99.

13. Es-Souni M, Es-Souni M, Fischer-Brandies H. On the properties of two binary NiTi shape memory alloys. Effects of surface finish on the corrosion behaviour and in vitro biocompatibility. Biomaterials. 2002;23:2887-94.

14. Wichelhaus A, Geserick M, Hibst R, Sander FG. The effect of surface treatment and clinical use on friction in NiTi orthodontic wires. Dent Mater. 2005;21:938-45.

15. Oshida Y, Sachdeva RC, Miyazaki S. Microanalytical characterization and surface modification of TiNi orthodontic archwires. Biomed Mater Eng. 1992;2:51-69.

16. Trepanier C, Tabrizian M, Yahia LH, Bilodeau L, Piron DL. Effect of modification of oxide layer on NiTi stent corrosion resistance. J Biomed Mater Res. 1998;43:433-40.

17. Nakagawa M, Matsuya S, Shiraishi T, Ohta M. Effect of fluoride concentration and $\mathrm{pH}$ on corrosion behavior of titanium for dental use. J Dent Res. 1999;78:1568-72.

18. Hunt NP, Cunningham SJ, Golden CG, Sheriff M. An investigation into the effects of polishing on surface hardness and corrosion of orthodontic archwires. Angle Orthod. 1999;69:433-40.

19. Huang HH. Surface characterizations and corrosion resistance of nickel-titanium orthodontic archwires in artificial saliva of various degrees of acidity. J Biomed Mater Res A. 2005;74:629-39.

20. Grimsdottir MR, Hensten-Pettersen A. Surface analysis of nickel-titanium archwire used in vivo. Dent Mater. 1997;13:163-7.

21. Eliades T, Eliades G, Athanasiou AE, Bradley TG. Surface characterization of retrieved NiTi orthodontic archwires. Eur J Orthod. 2000;22:317-26.

\section{Acknowledgments}

This study was supported by the Spanish Ministry of Science and Technology (MAT2009-13547). 